\section{Bacillus cereus as the main casual agent of foodborne outbreaks in Southern Brazil: data from 11 years}

\author{
Bacillus cereus como principal agente etiológico \\ em surtos de intoxicação alimentar no Sul do \\ Brasil: dados de 11 anos
}

\begin{abstract}
Bacillus cereus como el principal agente causante de brotes de enfermedades alimentarias en el Sur de Brasil: datos de 11 años
\end{abstract}

\begin{abstract}
Foodborne diseases are a global concern. In Brazil, the most prevalent pathogen found in foodborne outbreaks is Salmonella sp. (14.4\%), followed by Staphylococcus aureus (7.7\%), Escherichia coli (6.5\%), and Bacillus cereus (3.1\%). With the aim to perform a regional detailed analysis of foodborne intoxication, we analyzed 253 outbreaks' profile reports to Food Surveillance team of the General Secretariat of Health Surveillance of Porto Alegre, Rio Grande do Sul State, between 2003 and 2013. In contrast to what was most notified in Brazil, in Porto Alegre the main outbreak agent identified was $\mathrm{Ba}$ cillus cereus (32.2\%) and, based on the patient symptoms, most cases were linked to enterotoxin production. The majority of the outbreaks were linked to the ingestion of food containing cereals or sauces poorly kept at environment temperature during the stock or preparation. We believe that, due to the compulsory use of pasteurized eggs in our city, Salmonella sp. outbreaks are less important here.
\end{abstract}

Bacillus cereus; Foodborne Diseases; Enterotoxins; Disease Outbreaks
COMUNICAÇÃO BREVE

BRIEF COMMUNICATION
Silvia Adriana Mayer Lentz 1

Paula Marques Rivas 2

Marisa Ribeiro de Itapema Cardoso 3

Daiana de Lima Morales 4

Fabiana Cassel Centenaro 2

Andreza Francisco Martins 1,5

doi: 10.1590/0102-311X00057417

\author{
Correspondence \\ A. F. Martins \\ Programa de Pós-graduação em Microbiologia Agrícola e do \\ Ambiente, Universidade Federal do Rio Grande do Sul. \\ Rua Sarmento Leite 500, sala 210, Porto Alegre, RS \\ 90050-170, Brasil. \\ andrezafm20@gmail.com \\ 1 Programa de Pós-graduação em Microbiologia Agrícola e do \\ Ambiente, Universidade Federal do Rio Grande do Sul, Porto \\ Alegre, Brasil. \\ 2 Coordenadoria Geral de Vigilância em Saúde de Porto Alegre, \\ Porto Alegre, Brasil. \\ 3 Faculdade de Medicina Veterinária, Universidade Federal do \\ Rio Grande do Sul, Porto Alegre, Brasil. \\ ${ }_{4}$ Laboratório de Pesquisa em Resistência Bacteriana, Hospital \\ das Clínicas de Porto Alegre, Porto Alegre, Brasil. \\ 5 Departamento de Microbiologia, Universidade Federal do Rio \\ Grande do Sul, Porto Alegre, Brasil.
}


The occurrence of foodborne diseases has increased significantly worldwide. They are caused by ingesting food or water contaminated with chemical or biological agents, mainly viruses and/or bacteria 1. According to the Department of Health Surveillance, Brazilian Ministry of Health, between 2000 and 2015, there were 10,666 foodborne diseases outbreaks in Brazil, affecting 209,240 people and with a mortality rate of $0.05 \%$. Salmonella sp. was the most prevalent pathogen (14.4\%), followed by Staphylococcus aureus (7.7\%) and Escherichia coli (6.5\%). Bacillus cereus was the fourth causative agent (3.1\%). It is noteworthy that in most cases (58.5\%), it was not possible to identify the microorganism associated with the outbreak 2 .

In the United States, most bacterial foodborne illnesses were caused by non-typhoid Salmonella spp. (11\%) 3. It has caused one million of foodborne illnesses, with 19,000 hospitalizations and 380 deaths 4 . On the other hand, in Republic of Korea, where rice and grains are widely consumed, the potential risk of emetic syndrome associated to toxin-producing B. cereus was reported to be high 5 . Furthermore, the $B$. cereus was the second most frequent causative agent associated to foodborne outbreaks in France between 2006 and 2014, followed by S. aureus 6 . Its importance in this country is partly due to the participation of national health and food safety authorities in the epidemiological and microbiological investigations of suspected foodborne outbreaks 7. B. cereus is recognized as an opportunistic pathogen, causing gastrointestinal symptoms associated with the production of cereulide (emetic toxin) or enterotoxin (diarrheal syndrome associate). Therefore, the selective enrichment of emetic strains and the ability to sporulate made these organisms able to enter easily in the food chain; consequently, they are of great concern in recent years 8 .

Thus, the aim of this study was to evaluate the data from foodborne outbreaks notified in Porto Alegre, Rio Grande do Sul State, Brazil, that were associated to B. cereus.

\section{Methodology}

\section{Data source}

This was a retrospective study, using data obtained in the surveillance system from 2003-2013. A foodborne disease outbreak is defined as an occurrence of two or more cases with similar illness, resulting from ingestion of a common food or beverage 9 . The notification was done by hospitals, boarding schools, schools, prisons, or the community 10. Each outbreak have been reported to the Department of Food Surveillance from Porto Alegre, recorded on the Figure 1a (Form 1), and inserted on the Brazilian National Information System for Notifiable Diseases (SINAN). Local health authorities interviewed patients and/or parents to obtain information about the exposure (Figure 1a; Form 2). After analyzing the data, the hypotheses about the etiologic agent and suspected food were elaborated, and the inspection was done with focus on processing controls 10 .

Patients' and suspected foods' samples were collected for analysis by the Regional Reference Laboratory (LACEN/RS), according to the compendium of methods for microbiological examination of foods of the American Public Health Association 11, as part of the outbreak surveillance program investigated in our city. The definition of incriminated food and causative agent is based on the epidemiological-clinical data collected during the investigation. The final report (Figure 1b; Form 5) of the outbreak is inserted in the SINAN 10.

\section{Epidemiologic investigation}

Epidemiological research was conducted in all outbreaks caused by B. cereus. Data were collected from research reports (Figure 1a; Forms 1 and 2) and cases were grouped in: exposed (who have eaten the incriminated food) and affected (who had eaten the incriminated food and presented symptoms). 
Figure 1

Forms used for data collection.

1a) Forms 1 and 2

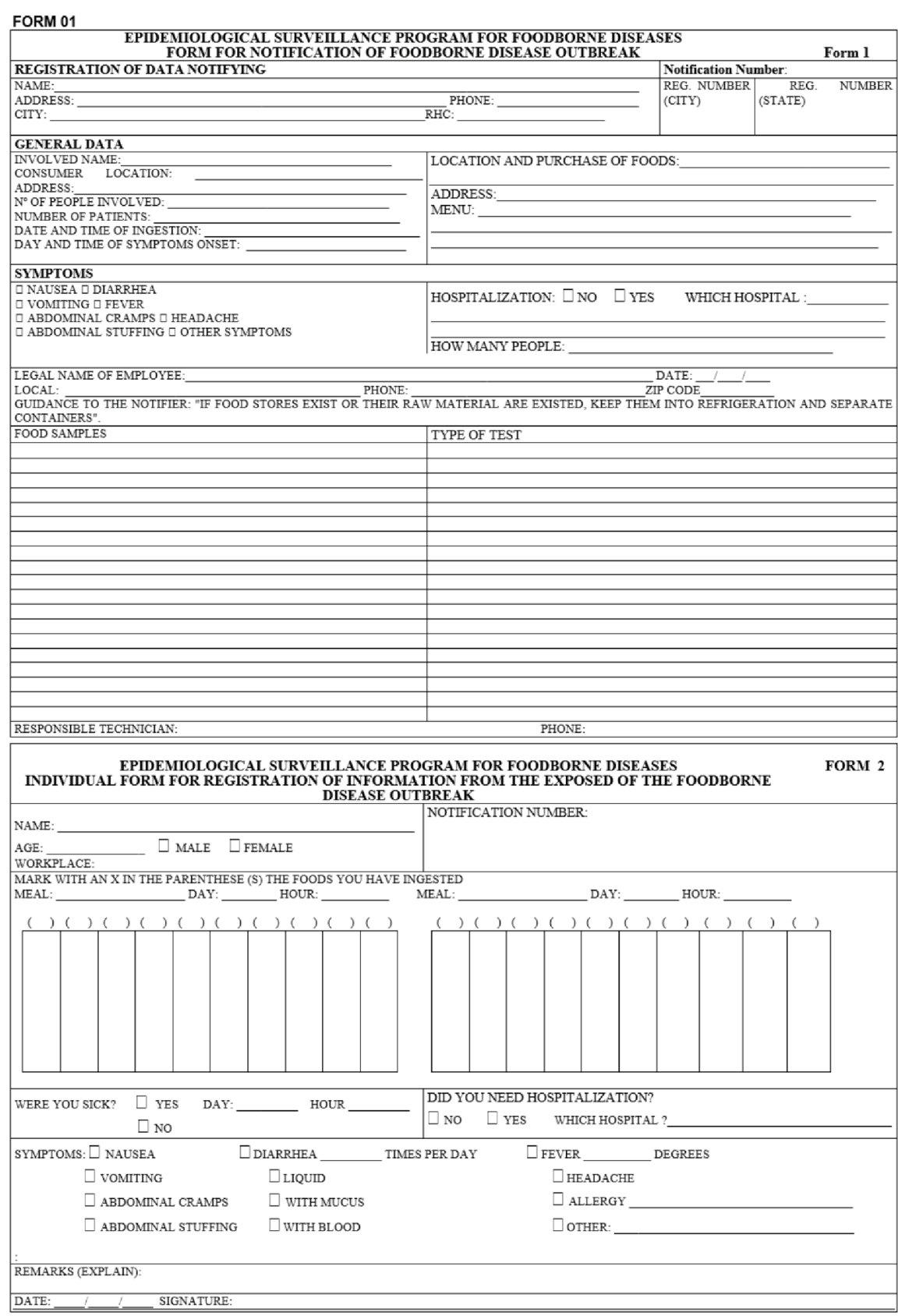

(continues) 
Figure 1 (continued)

1b) Form 5

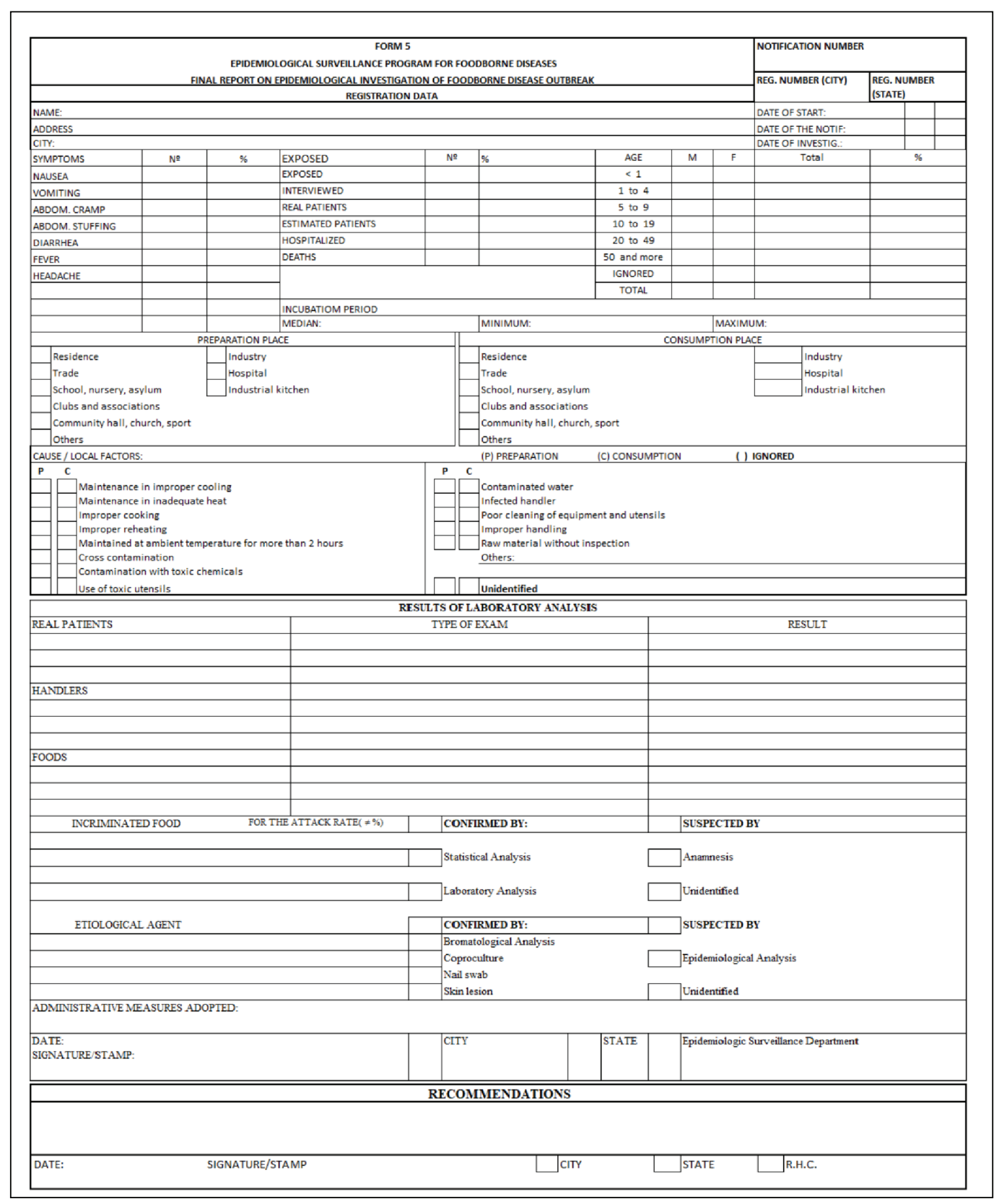

The suspected foods were grouped as follow:

- Snack bar: the food was prepared and/or ate at this type of premise, such as pastel, sandwich, cake, fried eggs, and hot dog;

- Food with sauce: all foods prepared with sauce, such as meat, vegetables, pasta, shrimp, and cream soup;

- Cereals: all foods prepared with cereals, such as bean, lentil, and rice;

- Others: any other food associated to an outbreak. 


\section{Results}

During 11 years, 253 outbreaks were notified, involving 9,592 (68/100,000 inhabitants/year) subjects. Thirty-nine outbreaks were excluded from the study due to the lack of information. Of the 214 outbreaks included, in 118 (55.14\%) it was possible to identify the pathogen, as follows: 38 (32.2\%) B. cereus, 33 (27.97\%) C. perfringens, 28 (22.89\%) Salmonella sp., 27 (22.88\%) S. aureus and 9 (7.62\%) E. coli. It is noteworthy that in $22(18.64 \%)$ outbreaks, more than one pathogen was identified.

Considering only the outbreaks associated with B. cereus, 2,435 (17/100,000 inhabitants/year) people were exposed and 346 (2.4/100,000 inhabitants/year) became ill. The central area of the city recorded the highest number of cases (50\%), followed by the northwestern area (21\%). The mean time between the onset of symptoms and the notification was 2 days, and between notification and investigation was less than 1 day.

Among the affected, 182 (52.6\%) were men, and most were aged between 20 - 49 years (64.7\%). The main symptoms reported by the affected were: diarrhea, cramps, and sickness. The mean incubation time was 12 hours (IQR = 5.75 hours). Three patients $(0.87 \%)$ were hospitalized, and no deaths were reported. Table 1 summarizes the characteristics of the patient cases. We found that, in $73 \%$ of the cases, the suspected food was prepared and eaten in restaurants; moreover, snacks and foods with sauce were the main incriminated foods. The causative factors were: to be exposed to ambient temperature for over two hours (17.6\%) or stored in inadequate temperature (16.2\%) (Table 2).

Table 1

Characteristics of cases' patients, Bacillus cereus. Porto Alegre, Rio Grande do Sul State, Brazil, 2003-2013.

\begin{tabular}{lc}
\hline Characteristics & Case patient $\mathbf{( N}=\mathbf{3 4 6})$ \\
& $\mathbf{n}(\%)$ \\
\hline Symptoms & \\
$\quad$ Diarrhea & $225(65.0)$ \\
Cramp & $212(61.0)$ \\
Sickness & $155(45.0)$ \\
Vomit & $82(24.0)$ \\
Headache & $29(8.0)$ \\
Bloating & $29(8.0)$ \\
Fever & $2(1.0)$ \\
Others & $2(1.0)$ \\
Incubation in hours (median \pm IQR) & $12 \pm 5.75$ \\
Men & $182(52.60)$ \\
Age in years (range) & \\
$<1$ & $0(0.0)$ \\
1-4 & $25(7.23)$ \\
$5-9$ & $22(6.36)$ \\
$10-19$ & $36(10.4)$ \\
$20-49$ & $224(64.74)$ \\
$\geq 50$ & $33(9.54)$ \\
Ignored & $6(1.73)$ \\
Total exposed & 2,435 \\
Affected & $346(100.0)$ \\
Hospitalized & $3(0.86)$ \\
Deaths & $0(0.0)$ \\
\hline
\end{tabular}

IQR: inter-quartile range. 
Table 2

Characteristics reported during the outbreaks, Bacillus cereus. Porto Alegre, Rio Grande do Sul State, Brazil, 2003-2013.

\begin{tabular}{|c|c|}
\hline Factors & $\begin{array}{c}\text { Outbreak ( } \mathrm{N}=38) \\
\mathrm{n}(\%)\end{array}$ \\
\hline \multicolumn{2}{|l|}{ Food preparation site } \\
\hline Home & $3(7.90)$ \\
\hline Restaurant * & $28(73.70)$ \\
\hline Hospital & $0(0.00)$ \\
\hline Institution ** & $4(10.50)$ \\
\hline Others & $3(7.90)$ \\
\hline \multicolumn{2}{|l|}{ Food consumption site } \\
\hline Home & $8(21.00)$ \\
\hline Restaurant * & $20(52.60)$ \\
\hline Hospital & $0(0.00)$ \\
\hline Institution ** & $8(21.00)$ \\
\hline Others & $2(5.40)$ \\
\hline \multicolumn{2}{|l|}{ Suspected foods } \\
\hline Snack & $9(23.70)$ \\
\hline Food with sauce & $9(23.70)$ \\
\hline Cereals & $5(13.20)$ \\
\hline Others & $6(15.70)$ \\
\hline No identified & $9(23.70)$ \\
\hline \multicolumn{2}{|l|}{ Suspected causality } \\
\hline Inadequate cooling & $7(10.29)$ \\
\hline Inadequate heat & $11(16.18)$ \\
\hline Inadequate cooking & $2(2.94)$ \\
\hline Room temperature over 2 hours & $12(17.65)$ \\
\hline Cross contamination & $5(7.35)$ \\
\hline Contaminated water & $0(0.00)$ \\
\hline Improper manipulation & $8(11.76)$ \\
\hline Unsatisfactory hygiene & $3(4.41)$ \\
\hline Others & $6(8.82)$ \\
\hline Unidentified & 14 (20.59) \\
\hline
\end{tabular}

* Including snack bar, fast food, self-service;

** Including school, church, club, home-care, headquarters, day care.

\section{Discussion}

Porto Alegre is a city with $496,682 \mathrm{~km}^{2}$ area and 1,409,351 inhabitants. In our study, most of the cases (50\%) were reported in the central region of the city. This data is reasoned by the pronounced number of people who work in this region, plus the considerable number of inhabitants $(276,799)$ and, in addition, approximately $20 \%(7,771)$ of the total food service establishments are located in the city center. Another argument is the high Human Development Index - HDI (0.805 of 1.0), that indicates a high socio-economic and cultural level of the inhabitants, who can have more meals in restaurants and have a better understanding of the importance of food intoxication reporting 12 .

Several toxins have been described in B. cereus outbreaks, and they cause two types of foodborne diseases. The enterotoxins have been linked to the diarrheal form of the disease, while the cereulide has been linked to emetic form 13. In the diarrheal syndrome, toxin production occurs after the bacterial growth in the patient guts ( 8 to 24 hours of incubation), while in the emetic syndrome the cereulide, the toxin is formed and consumed within the food 14. 
In our study, the mean incubation period reported by the affected patients was 12 hours and the most common symptom was diarrhea, followed by abdominal pain. These results assume that most of the outbreaks were associated with diarrheal syndrome. This situation is similar to that found in Hungary, Finland, Bulgaria, and Norway, where the B. cereus diarrheal-type intoxication has been reported more frequently than the emetic syndrome 11.

The main foods incriminated in our study were snacks and food with sauce, and the main cause of contamination was its exposition at ambient temperature for more than two hours and storage in an inadequate temperature. Blackburn \& McClure 15 reported that the diversity of countries involved in B. cereus outbreaks reflects the different eating habits and diverse niches where it can proliferate. Meals based on cold or cooked rice, pasteurized cream, spaghetti, mashed potatoes, and vegetable sprouts are common in Japan, Great Britain, Finland, and the USA, where emetic intoxication is more prevalent. Soups, milk and dairy products, meat dishes, and spices are usually consumed in Europe and North America, where diarrheal intoxication predominates 15. In our study, the incriminated foods suggest the influence of eating habits from the central region, where there is a large circulation of people who choose faster meals, such as snacks or self-service restaurants.

As reported in other studies, $B$. cereus could enter the food production chain at different points due to its ability to sporulate 16 . Furthermore, the months of May, November, and December were those with the highest incidence of cases. These months are characterized by heat and humidity, favoring the microbial proliferation.

According to the Food Surveillance team, Salmonella sp. is not the most prevalent pathogen in Porto Alegre. A hypothesis for explaining this finding is that in only $55.14 \%$ of the cases it was possible to identify the pathogen. The substantial number of cases with unidentified agent can be explained by the difficulty in recovering the food due to a late notification. Another situation that contributed to these results was the implementation of a program to prevent and control the Salmonella's outbreaks by restricting the use of raw eggs in commercial food services. In addition to that, this result can be justified by actions of the Department of Food Surveillance from Porto Alegre, Ministry of Agriculture, South Association of Poultry, and the State Department of Health on the production and trading of poultry and eggs in the Southern state, with focus on inspections, sanitary education, and more control over the raw materials that can carry the Salmonella sp. to food.

Finally, our findings show the importance of B. cereus in foodborne diseases, and the need for constant monitoring these cases to detect failures in the food preparation process.

\section{Contributors}

S. A. M. Lentz, P. M. Rivas and F. C. Centenaro participated in the data collection and article writing. D. L. Morales contributed in the article writing. M. R. I. Cardoso and A. F. Martins participated in the data analysis and article writing.

\section{Acknowledgments}

We thank the surveillance departments on food and epidemiology of the city of Porto Alegre, for providing the data used in this work.

\section{References}

1. Hald T, Aspinall W, Devleesschauwer B, Cooke R, Corrigan T, Havelaar AH, et al. World Health Organization estimates of the relative contributions of food to the burden of disease due to selected foodborne hazards: a structured expert elicitation. PLoS One 2016; 11:e0145839.

2. Secretaria de Vigilância em Saúde, Ministério da Saúde. Doenças transmitidas por alimentos: informações técnicas. http://foodsafetybrazil. org/surtos-alimentares-no-brasil-dados-atua lizados-em-2015 (accessed on 28/Mar/2016).

3. Scallan E, Hoekstra RM, Angulo FJ, Tauxe RV, Widdowson M, Roy SL, et al. Foodborne illness acquired in the United States: major pathogens. Emerg Infect Dis 2011; 17:7-15. 
4. Division of Foodborne, Waterborne and Environmental Diseases, National Center for Emerging and Zoonotic Infectious Diseases, Centers for Disease Control and Prevention. Pathogens causing US foodborne illnesses, hospitalizations, and deaths, 2000-2008. https://www.cdc.gov/foodborneburden/PDFs/ pathogens-complete-list-01-12.pdf (accessed on $10 / \mathrm{Jul} / 2017$ )

5. Kim JB, Jeong HR, Park YB, Kim JM, Oh DH. Food poisoning associated with emetic-type of Bacillus cereus in Korea. Foodborne Pathog Dis 2010; 7:555-63.

6. Santé Publique France. Données relatives aux toxi-infections alimentaires collectives déclarées en France en 2013. http://invs.san tepubliquefrance.fr/Dossiers-thematiques/ Maladies-infectieuses/Risques-infectieux-dorigine-alimentaire/Toxi-infections-alimen taires-collectives/Donnees-epidemiologiques (accessed on Dec/2015).

7. Glasset B, Herbin S, Guillier L, Cadel-Six S, Vignaud M-L, Grout J, et al. Bacillus cereusinduced food-borne outbreaks in France, 2007 to 2014: epidemiology and genetic characterisation. Euro Surveill 2016; 21:30413.

8. Ehling-Schulz M, Fricker M, Scherer S. Bacillus cereus, the causative agent of an emetic type of food-borne illness. Mol Nutr Food Res 2004; 48:479-87.

9. Olsen SJ, MacKinnon LC, Goulding JS, Bean NH, Slutsker L. Surveillance for foodbornedisease outbreaks: United States, 1993-1997. MMWR CDC Surveill Summ 2000; 49:1-62.
10. Departamento de Vigilância Epidemiológica Secretaria de Vigilância em Saúde, Ministério da Saúde. Manual de doenças transmitidas por alimentos. Brasília: Ministério da Saúde; 2010.

11. Kramer JM, Gilbert RJ. Bacillus cereus and other Bacillus species. In: Doyle MP, editor. Foodborne bacterial pathogens. New York: Marcel Dekker Inc.; 1989. p. 21-70.

12. Programa das Nações Unidas para o Desenvolvimento; Instituto de Pesquisa Econômica Aplicada; Fundação João Pinheiro. Atlas do desenvolvimento humano no Brasil 2013. http:// www.atlasbrasil.org.br/2013/pt/perfil_m/por to-alegre_rs (accessed on Dec/2015).

13. Stiles BG, Pradhan K, Fleming JM, Samy RP, Barth H, Popoff MR. Clostridium and Bacillus binary enterotoxins: bad for the bowels and eukaryotic being. Toxin 2014; 6:2626-56.

14. Ehling-Schulz M, Frenzel M, Gohar M. Foodbacteria interplay: pathometabolism of emetic Bacillus cereus. Front Microbiol 2015; 6:704.

15. Blackburn C, McClure P. Foodborne pathogens: hazards, risk analysis and control. Cambridge: Woodhead Publishing/Boca Raton: CRC Press; 2002.

16. Nicholls M, Purcell B, Willis C, Amar CF, Ranagarajah S, Chamberlain D, et al. Investigation of an outbreak of vomiting in nurseries in South East England, May 2012. Epidemiol Infect 2016; 144:582-90. 


\section{Resumo}

As doenças de veiculação alimentar representam um problema de ordem global. No Brasil, o patógeno mais prevalente em surtos de intoxicação alimentar é a Salmonella sp. (14,4\%), seguido pelo Staphylococcus aureus (7,7\%), Escherichia coli $(6,5 \%)$ e Bacillus cereus $(3,1 \%)$. Com o objetivo de realizar uma análise regional detalhada da intoxicação alimentar, examinamos os relatórios de 253 surtos, notificados à equipe de Vigilância de Alimentos da Coordenadoria Geral de Vigilância em Saúde de Porto Alegre, Rio Grande do Sul, entre 2003 e 2013. Ao contrário do que é notificado no Brasil, em Porto Alegre, identificamos como principal agente etiológico, o Bacillus cereus (32,2\%) $e$ de acordo com os sintomas dos pacientes, a maioria dos casos esteve associada à produção de enterotoxina. A maioria dos surtos foram associados à ingestão de alimentos que continham cereais ou molhos mantidos à temperatura ambiente durante o armazenamento ou preparação. O uso compulsório de ovos pasteurizados em Porto Alegre pode explicar a relativa escassez de surtos de Salmonella sp. no município.

Bacillus cereus; Doenças Transmitidas por Alimentos; Enterotoxinas; Surtos de Doenças

\section{Resumen}

Las enfermedades transmitidas a través de la comida son una preocupación de carácter global. En Brasil, el patógeno encontrado de forma más prevalente en los brotes de epidemias alimentarias es la Salmonella sp. (14,4\%), seguida por el Staphylococcus aureus (7,7\%), Escherichia coli (6,5\%), y el Bacillus cereus (3,1\%). Con el fin de realizar un análisis regional detallado de los brotes de infecciones alimentarias, analizamos el perfil de 253 brotes, registrados por el servicio de Vigilancia Alimentaria de la Secretaría General de Vigilancia en Salud de Porto Alegre, Rio Grande do Sul, entre 2003 y 2013. En contraste con lo que fue más notificado en Brasil, en Porto Alegre el principal agente causante de brotes fue identificado como el Bacillus cereus (32.2\%) y, basado en los síntomas del paciente, la mayoría de los casos estaban relacionados con la producción de la enterotoxina. Muchos de los brotes estaban relacionados con la ingesta de comida que contenía cereales o salsas mal conservadas a temperatura ambiente durante el almacenaje o la preparación. Creemos que, debido a la utilización obligatoria de huevos pasteurizados en nuestra ciudad, los brotes de Salmonella sp. son menos relevantes aquí.

Bacillus cereus; Enfermedades Transmitidas por los Alimentos; Enterotoxinas; Brotes

de Enfermedades
Submitted on 03/Apr/2017

Final version resubmitted on 05/Dec/2017

Approved on 07/Dec/2017 